\title{
EFFECTS OF LIPID A ANALOGUES OF THE STRAINS OF $E$. COLI ON COMPLEMENT AND MYELOPEROXIDASE ACTIVATION IN MYOCARDIAL REPERFUSION FOLLOWING ISCHAEMIA IN RATS
}

\author{
${ }^{1}$ Dubničková M. - ${ }^{2}$ Stankovičová T. $-{ }^{1}$ Bukovský M. $-{ }^{2}$ Kuželová M. \\ ${ }^{1}$ Department of Cell and Molecular Biology and ${ }^{2}$ Department of Pharmacology and \\ Toxicology, Faculty of Pharmacy, Comenius University, Bratislava, Slovak Republic
}

The aim of the study was to evaluate the ability of lipid A analogues obtained from the native strain (LAS) or strains of $E$. coli resistant to either an amine oxide (modLANO) or to a quaternary ammonium salt (modLBr) to reduce myocardial ischaemia and reperfusion injury in rats. The 0.5 , 2, 4, 24 h pretreatment of rats with lipid A from a strain of $E$. coli resistant to an amine oxide (modLANO $0.5 \mathrm{mg} / \mathrm{kg}$ i.v.) in an in vitro model of myocardial ischemia lasting $10 \mathrm{~min}$ followed by $10 \mathrm{~min}$ reperfusion did not reduce the myeloperoxidase (MPO) and complement activities. In an in vivo study, the $24 \mathrm{~h}$ pretreatment of rats with modLANO in a dose of $0.5 \mathrm{mg} / \mathrm{kg}$ i.v. only significantly decreased both the MPO and complement activities in serum $(\mathrm{p}<0.01)$. The analogues of lipid A indicate abilities to influence the myocardial ischaemia-reperfusion injury in times-dependent and structures-dependent ways.

Keywords: lipid A - MPO - complement - ischaemia - reperfusion

\section{INTRODUCTION}

Myocardial ischaemia and reperfusion injury (IRI) is known to produce factors that may play a role in activation of neutrophils, in addition to increased intracellular calcium levels and endothelial dysfunction [1]. Accumulation of neutrophils in the cardiac tissue after ischaemia and reperfusion is increased by various chemo-attractants, one of which is a product of complement activation. Neutrophils in this process, which involves the enzyme myeloperoxidase (MPO), are generating oxygen-derived free radicals. These radicals, together with the lysosomes and the terminal complement system may damage the heart tissue [2,3]. Many substances had been proven to have protective effects against IRI and an important task in future is to find the product able 
to influence the unwanted inflammatory reaction demonstrated by inhibition of neutrophils and of complement system.

The modification of lipid A structure on its glucosamine core, namely the elimination of phosphate groups at 1st position and the absence of the hydroxyl side chain at 3rd position (monophosphoryl lipid A-MLA) was found to reduce the deleterious effects of IRI [4]. In our previous work we have confirmed that lipid A analogues either from the original strain or strains of $E$. coli adapted to amine oxides or ammonium salt, were changed in composition of their fatty acids [5]. In certain concentrations these analogues are able to modulate the activities of leucocytes and to suppress the native response of immunity. We have also found that the immunomodulatory effects of analogues of lipid A are similar to MLA [6,7].

The aim of the experimental work was to investigate how the structural differences in lipid A analogues from the adapted resistant strains can modify the MPO activity of myocardial cells and complement activity of rat heart tissue or serum in in vitro and in vivo conditions during myocardial reperfusion injury.

\section{MATERIAL AND METHODS}

\section{The isolation of lipid A}

The strain of Escherichia coli ATCC 11229 was adapted to $820 \mathrm{mM}$ of 1-(methyldodecyl)dimethylamine oxide (ATDNO) or to $620 \mathrm{mM} 1$-(methyldodecyl)trimethylammonium bromide (ATDBr) cultivated in media with gradually increasing amphiphilic concentration. The analogues of lipid A were obtained from bacteria as described by Koščová et al. [7]. Concretely, modLANO (the lipid A from bacteria adapted to ATDNO), modLABr (the lipid A from bacteria adapted to ATDBr) and LAS were obtained from the native bacteria.

\section{Premedication of rats during the experiment}

The experiments were performed in accordance with the Proclamation of the Government of the Slovak Republic on January 14, 2009, Law No. 23/2009 in the Collection of Laws of the Slovak Republic, and in accordance with the local Ethical Committee of Comenius University in Bratislava, Faculty of Pharmacy. Male Wistar rats (200-300 g) (Anlab, Prague, Czech Republic) were divided into 10 groups.

In experiments either the $30 \mathrm{~min}$ or $2 \mathrm{~h}$, or $4 \mathrm{~h}$ or $24 \mathrm{~h}$ pretreatment of animals (i.v.) with modLANO at a of dose $0.5 \mathrm{mg} / \mathrm{kg}$ followed by ischaemia for 10 minutes and subsequent reperfusion of heart for 10 minutes with Langendorff technique was performed.

Rats were anesthetised with thiopental (45 mg/kg, i.p., SPOFA, CR). The hearts were then excised and connected to the perfusion system via a cannula inserted into the aorta. Isolated hearts were perfused retrogradely using Krebs-Henseleit solution, perfusion pressure was $7.5-7.9 \mathrm{kPa}$ and the solution was saturated with pneumoxide 
$\left(95 \% \mathrm{O}_{2}\right.$ and $5 \% \mathrm{CO}_{2}$ ), under $36.5-37^{\circ} \mathrm{C}$ temperature, $\mathrm{pH}$ 7.4. The heart was continuously superfused with Krebs-Henseleit solution [8]. Following cannulation the heart was stabilized for $20 \mathrm{~min}$, followed by $10 \mathrm{~min}$ stop-flow global ischaemia and 10 min reperfusion with Krebs-Henseleit solution $[9,10]$. At the end of reperfusion samples from the left ventricle of the heart were collected.

In the model of myocardial IRI in vivo, the saline or different type of lipid A analogues (modLANO at a dose of $0.5 \mathrm{mg} / \mathrm{kg}, \operatorname{modLABr}$ and LAS at a dose of 0.1 $\mathrm{mg} / \mathrm{kg}$ ) were administered to rats i.v. into the femoral vein $24 \mathrm{~h}$ before the $30 \mathrm{~min}$ ischaemia and subsequently the $2 \mathrm{~h}$ reperfusion of the left coronary artery was induced. Both the occlusion and reperfusion of left coronary artery in situ were prepared according to Leprán and Szekeres [11]. The rats were anesthetised with pentobarbital (SPOFA, CR), $45 \mathrm{mg} / \mathrm{kg}$, i.p. After the tracheal cannulation and thoracotomy, a ligature was placed loosely around the descending branch of the left coronary artery. The heart was put back into the thoracic cavity and the rat started to ventilate artificially with room air by a pump (CIIC, USA) at a rate of 50-60 breaths/min and in volume of 1.2 $\mathrm{ml} / 100 \mathrm{~g}$. After a $10 \mathrm{~min}$ stabilisation period, the left coronary artery was occluded for $30 \mathrm{~min}$, followed by $2 \mathrm{~h}$ reperfusion.

\section{Myeloperoxidase activity (MPO)}

The myocardial tissue samples from the left ventricle were homogenised in $50 \mathrm{mM}$ potassium phosphate buffer ( $\mathrm{pH}$ 6) containing $5 \mathrm{mM}$ EDTA $(10 \% \mathrm{w} / \mathrm{v})$ and centrifuged at $2400 \mathrm{~g}$ for $30 \mathrm{~min}$ at $4^{\circ} \mathrm{C}$. The pellets were resuspended (1:1) in phosphate buffers and in $0.5 \%$ hexadecylammonium bromide for solubilisation of myeloperoxidase [12].

The tissue suspensions or serum were adjusted with homogenisation by sonication (at $18 \mathrm{kHz}$ for $1 \mathrm{~min}$, SONIPREP $150 \mathrm{MSE}$, USA) and with centrifugation at $2400 \mathrm{~g}$ for $30 \mathrm{~min}$. The supernatant fractions were analysed for MPO activity. During processing the samples were kept on ice. The $0.1 \mathrm{ml}$ aliquot of the supernatant was mixed with 2.9 $\mathrm{ml}$ of $50 \mathrm{mM}$ potassium phosphate buffer ( $\mathrm{pH} \mathrm{6)}$ containing $0.167 \mathrm{mg} / \mathrm{ml}$ of odianisidine and $0.0005 \%$ hydrogen peroxide. The changes in absorbance at $490 \mathrm{~nm}$ due to the oxidation of o-dianisidine were monitored by a spectrophotometer (Dynatech, USA) at 0 and 5 minutes at $25^{\circ} \mathrm{C}$.

\section{Complement activity}

Myocardial tissue samples from the left ventricle were homogenised and the pellets were resuspended (1:1) in barbital buffer (pH 7.4). The ALEXIN (complement) was diluted in $1 \mathrm{ml}$ of distilled water and then diluted in barbital buffer solution $(1: 100)$ at $\mathrm{pH} 7.36$ and was pre-incubated at $37^{\circ} \mathrm{C}$ for $30 \mathrm{~min}$ with serum or homogenised tissue samples of myocardium in concentrations from 1.0 to $3.5 \mathrm{ml}$ in $0.5 \mathrm{ml}$ increments, and centrifuged at $2200 \mathrm{~g}$ for $15 \mathrm{~min}$.

The lyophilised haemolytic system contained rabbit IgM antisheep erythrocyte antibodies - the 5 units of amboceptor per $\mathrm{ml}$ (Institute for Serum and Vaccine 
Production, Prague, Czech Republic) with 5\% of volume of sensitised sheep erythrocytes. The system was diluted with barbital buffer solution at 1:2000. Samples were composed of the mixture of diluted ALEXIN (complement) with $1 \mathrm{ml}$ of the haemolytic system. The control samples contained erythrocytes after the spontaneous lysis, $100 \%$ lysis of erythrocytes and the control serum. The samples were incubated 60 min at $37^{\circ} \mathrm{C}$ then softly mixed and centrifuged at $2200 \mathrm{~g}$ for $10 \mathrm{~min}$. The haemoglobin was released in supernatant and was measured by a spectrophotometer (Dynatech, USA) at $410 \mathrm{~nm}$. The A410 of spontaneous lysis solution (the absorbance of the spontaneous lysis sample for the best results was below 0.15) was subtracted from the A410 of the sample solutions and from the A410 after 100\% lysis solution. These values represent the real A410. Further, the percentage of the lysis in each reaction mixture sample was calculated according to [13].

\section{Statistical analysis}

Statistical comparison between the control and the samples was performed by Student's t-test. The number of animals in in vitro and in vivo experiment was 6-11 rats in each experimental group and 14 in control groups. The value $p<0.05$ was regarded as statistically significant.

\section{RESULTS}

Premedication of modLANO in rats in relation to the time of administration under in vitro conditions shows that the control complement activity $(\mathrm{CH} 50)$ was $10.1 \pm 2.9 / \mathrm{ml}$ of tissue sample. Activity of complement expressed as $\mathrm{CH} 50(17.8 \pm 4.9 / \mathrm{ml}$ of tissue sample, $\mathrm{p}<0.05$ ) was significantly changed (Fig. 1). Relative activity 1.8 times higher compared with the control sample (1.0) was observed after pretreatment of rats in $0.5 \mathrm{~h}$ with $0.5 \mathrm{mg} / \mathrm{kg}$ modLANO. During the longer pretreatment time $(2,4$ or $24 \mathrm{~h})$ with 0.5 $\mathrm{mg} / \mathrm{kg}$ modLANO the complement activity $(10.3 \pm 3.5 / \mathrm{ml}, 9.2 \pm 3.9 / \mathrm{ml}, 10.1 \pm 2.6 / \mathrm{ml}$ tissue samples, respectively) was similar to the control value. MPO activity significantly increased after $4(\mathrm{p}<0.01)$ and $24 \mathrm{~h}(\mathrm{p}<0.05)$ pretreatment with the same lipid A analogue in comparison with control (Fig. 1). MPO tissue activity expressed as the difference of absorbance between 0 and 5 min increased from $0.129 \pm 0.036$ of control to $0.183 \pm 0.024$ and $0.174 \pm 0.029$, respectively. The MPO activities were not changed after $0.5 \mathrm{~h}(0.158 \pm 0.046)$ and $2 \mathrm{~h}$ pretreatment time $(0.143 \pm 0.040)$ (Fig. 1). 


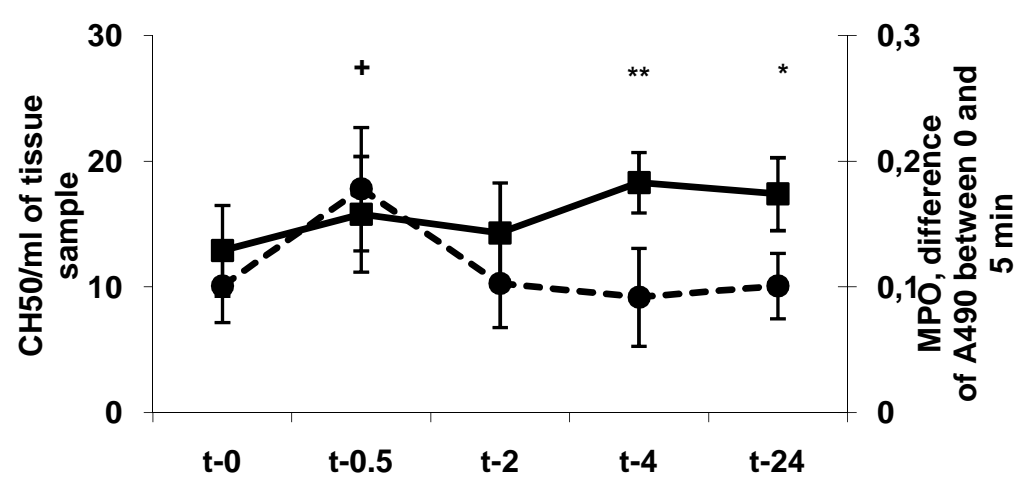

Figure 1. The time effect of pretreatment with modLANO administered at $0.5 \mathrm{mg} / \mathrm{kg}$ i.v. on both complement $(\mathrm{CH50} / \mathrm{ml})$ and myeloperoxidase (MPO) activities in the rat myocardial tissue in experiments performed in vitro. ModLANO is lipid A gained from $E$. coli adapted to amine oxide, $\mathrm{CH50}$ activity measured as total haemolytic titre, MPO is determined as changes in absorbance (490 nm) due to the oxidation of o-dianisidine within 0 and $5 \mathrm{~min}$ of incubation, $t-0$ is a control sample from animals without pretreatment after the ischaemia-reperfusion, $t-0.5,2,4$ and 24 are samples from the pretreated rats for $0.5,2,4$ and 24 hours after the ischaemia-reperfusion. Data are expressed as mean \pm SD, the symbol for the CH 50/ml: $+\mathbf{p}<0.05$; the symbol for the MPO: $* \mathbf{p}<0.05, * * p<0.01$; t vs t-0.

The types of lipid A analogues effective as modulators in rats in in vivo conditions show the results of haemolytic complement and MPO activities in serum. These results are shown in Figs. 2A, 2B. Notable was the finding that modLANO analogue in a dose of $0.5 \mathrm{mg} / \mathrm{kg}$ after $24 \mathrm{~h}$ pretreatment may modulate the IRI in the heart by reducing both the haemolytic (CH50 $17.67 \pm 0.07 / \mathrm{ml}$ of serum vs. control $22.79 \pm 0.86 / \mathrm{ml}$ ) and MPO activities (1.271 \pm 0.004 vs. control 1.428 \pm 0.07 ; p<0.01) (Figs. 2A, 2B).

The haemolytic activity (Fig. 2A) was significantly stimulated by the LAS and modLABr lipid A analogues $(19.49 \pm 0.46 / \mathrm{ml}$ and $33.11 \pm 1.56 / \mathrm{ml}$ of serum vs. $18.19 \pm 1.04 / \mathrm{ml}$ in control, $\mathrm{p}<0.05$ and 0.01 ). Premedication of animals with these analogues of lipid A did not activate MPO in the serum (Fig. 2B). 


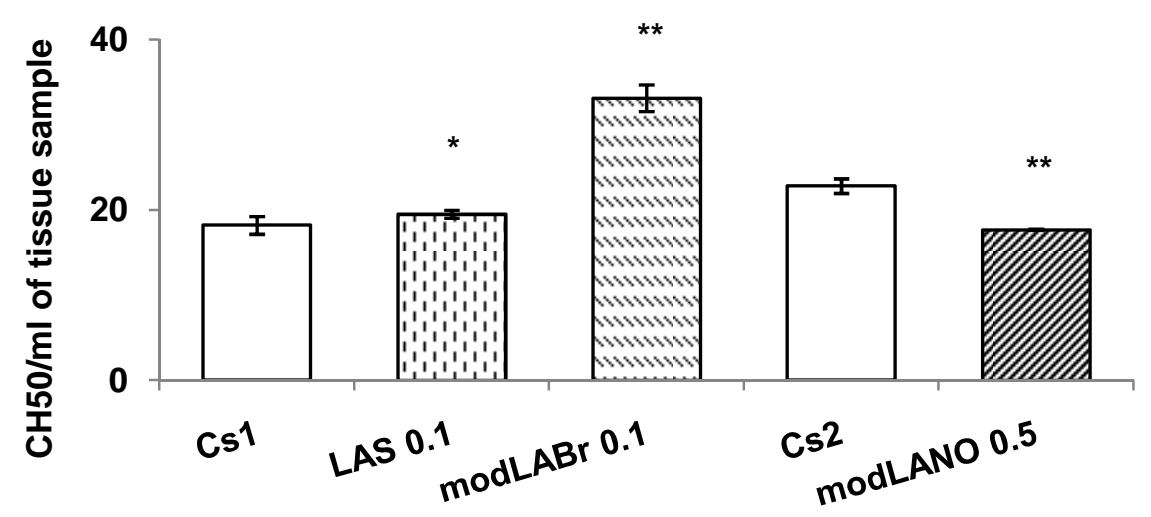

samples of lipid $A, \mathrm{mg} / \mathrm{kg}$

B

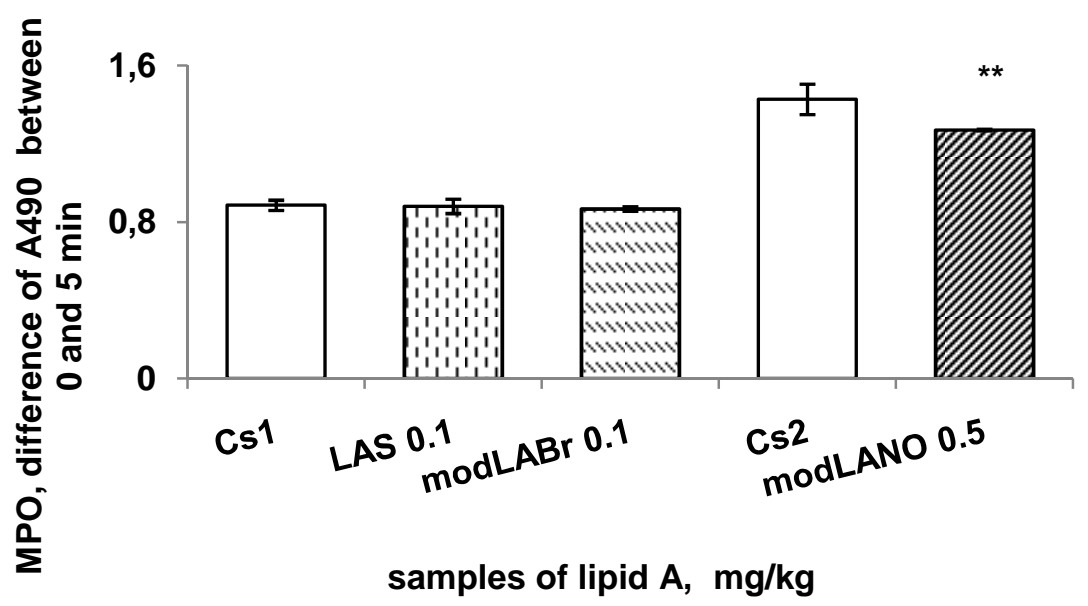

Figure 2. The effect of lipid A analogues on both complement (CH50/ml) (part A) and myeloperoxidase (MPO) (part B) activities in the rat serum in experiments performed in vivo. LAS 0.1 is a lipid A at a dose of $0.1 \mathrm{mg} / \mathrm{kg}$ gained from the native strain of $E$. coli, modLABr 0.1 is a lipid $A$ at a dose of 0.1 $\mathrm{mg} / \mathrm{kg}$ adapted to the ammonium salt and modLANO 0.5 is a lipid $\mathrm{A}$ at a dose of $0.5 \mathrm{mg} / \mathrm{kg}$ gained from $E$. coli adapted to the amine oxide, Cs1 is a control sample for LAS and modLABr, Cs2 is a control sample for modLANO, the controls are from two independent experiments. Data are expressed as mean $\pm \mathrm{SD}, * \mathbf{p}<0.05, * * \mathbf{p}<0.01$ modified lipids A vs. corresponding controls. 


\section{DISCUSSION}

Currently various attempts are being made to decrease both MPO and complement activities in the course of myocardial IRI [14,15,16,17].

Our results suggest that modified analogue of lipid A does not express any effect in the myocardial tissue itself related to the decrease in complement and MPO activity in in vitro experiments, when ischaemia and reperfusion are short-term. We could conclude that the changes in immunoactivities, considered as cardioprotective, do not correlate with the effective changes in functional parameters of myocardium after pretreatment with modLANO as described in the work of Kuželová et al. [18,19].

The protection from IRI in the heart, which the lipids A mostly produce after longer period of administration before ischaemia, is not sufficiently elucidated. All these results mean the reduction of values in complement system together with MPO in particular time, in vitro, were the motivation to use the $24 \mathrm{~h}$ pretreatment of rats with lipid A analogues in subsequent in vivo experiments.

In experiments in vivo, only the modLANO analogue at $0.5 \mathrm{mg} / \mathrm{kg}$ dose significantly and in a similar way decreased the complement and MPO activity. Considering the administered dose, relatively the same results with other lipid A analogues were found by other authors [20,21]. They also found that myocardial infarction was reduced to a higher extent after administration of $0.5 \mathrm{mg} / \mathrm{kg}$ of MLA. The $24 \mathrm{~h}$ pretreatment of animals with 0.3 and $0.45 \mathrm{mg} / \mathrm{kg}$ doses of MLA, prior to global ischaemia improves the recovery from post-ischaemic ventricular dysfunction. Similar results related to the dose of $0.5 \mathrm{mg} / \mathrm{kg}$ of modLANO were found when MLA in doses of $0.35 \mathrm{mg} / \mathrm{kg}$ and 0.65 $\mathrm{mg} / \mathrm{kg}$ was administered to rabbits and dogs. The observations are consistent with the fact that reduction of local production of complement proteins significantly decreases the degree of the myocardial injury after ischaemia and escalates the manifestation of complement activity with reperfusion of the heart [14]. Contrary to these effects, the results obtained from in vitro experiments are not comparable with the results of observations of whole animals.

Nevertheless our results confirm that pretreatment of animals using the analogues of lipid A was not as great as the protective effect of MLA. The results in literature show that the duration of ischaemia and reperfusion may influence the protective effect of lipid A equally as the suppression of complement and MPO activities of IRI [17]. This could be the reason that in connection with time the organism can endogenously protect the tissues of the heart.

We conclude that in our experiment a reduction in MPO and complement activities was observed only in in vivo experiments, but discordance with the in vitro experiments was also found. The analogues of lipid A indicate abilities to influence the myocardial injury in times-dependent and structures-dependent ways.

These results may help to understand the complexity of the impact of potential drugs on complement and MPO activity in the process of development of myocardial IRI.

Acknowledgement: This work has been supported by grants APVV 0354-07(MB). 


\section{REFERENCES}

1. MAXWELL, S.R.J.- LIP, G.Y.H.: Reperfusion injury: a review of the pathophysiology, clinical manifestations and therapeutic options. Int. J. Cardiol. 58, 1997, p. 95-117.

2. HANSEN, P.R.: Role of neutrophils in myocardial ischemia and reperfusion. Circulation 91, 1995, p. 1872-1885.

3. MONSINJON, T. - RICHARD, V. - FONTAINE, M.: Complement and its implications in cardiac ischemia/reperfusion: strategies to inhibit complement. Fundam. Clin. Pharmacol. 15, 2001, p. 293-306.

4. ELLIOTT, G.T.: Monophosphoryl lipid A induces delayed preconditioning against cardiac ischemia-reperfusion injury. J. Mol. Cell Cardiol. 30, 1998, p. 3-17.

5. DUBNIČKOVÁ, M. - ŘEZANKA, T. - KOŠČOVÁ, H.: Adaptive changes in fatty acids of E. coli strains exposed to a quaternary ammonium salt and an amine oxide. Folia Microbiol. 51, 2006, p. 371-374.

6. DUBNIČKOVÁ, M. - BUKOVSKÝ, M. - MLYNARČÍK, D.: Activation of human leucocytes by lipid A from $E$. coli strains adapted to quaternary ammonium salt and amine oxide. Folia Microbiol. 48, 2003, p. 543-547.

7. KOČŠOVÁ, H. - DUBNIČKOVÁ, M. - BUKOVSKÝ, M. - MLYNARČÍK, D.: Effects of LPS, Lipid A and polysaccharide from adapted strains of Escherichia coli on human leucocyte activity. Pharmazie 63, 2008, p. 147-150.

8. CURTIS, M.J. - HEARSE, D.J.: Reperfusion-induced arrhythmias are critically dependent upon occluded zone size: relevance to the mechanism of arrhythmogenesis. Cardiovasc. Res. 21, 1989, p. 625-637.

9. STANKOVIČOVÁ, T. - FRÝDL, M. - KUBICOVÁ, M. -BARÓNIKOVÁ, S. - NAGY, M. - GRANČAI, D. - ŠVEC, P.: (2001) The effect of ligustrum devalayanum isolated perfused rat heart. Exp.Clin. Cardiol. 6, 2001, p. 132-136.

10. WALKER, M.J.A. - CURTIS, M.J. - HEARSE, D.J. - CAMPBELL, R.W. - JANSE, M.J. - YELLON D.M. - COBBE S.M. - COKER S.J. - HARNESS S.J. - HARRON D.W.G. HIGGINS A. J. - JULIAN D.G. - LAB M.J. - MANNING A.S. - NORTHOVER B.J. PARRAT J.R. - RIEMERSMA R.A. - RIVA E. - RUSSELL D.C. - SHERIDAN D.J. WINSLOW E. - WOODWARD B: The Lambeth Conventions: guidelines for the study of arrhythmias in ischemia infarction, and reperfusion. Cardiovasc. Res. 22, 1988, p. 447-455.

11. LEPRÁN, I. - SZEKERES, L.: Effect of dietary sunflower oil on the severity of reperfusion - induced arrhythmias in anesthetized rats. J. Cardiovasc. Pharmacol. 19, 1992, p. 40-44.

12. MULLANE K.M. - KRAEMER R. - SMITH B.: Myeloperoxidase activity as a quantitative assessment of neutrophil infiltration into ischemic myocardium. J. Pharmacol. Methods 14, 1985, p. 157-167.

13. HARBECK, R.J. - GICLAS, P.C. (Eds.): Diagnostic Immunology Laboratory Manual. Raven Press, New York, 1991, p. 21-25.

14. BUERKE, M. - PRUFER, D. - DAHM, M. - OELERT, H. - MEYER, J. - DARIUS, H.: Blocking of classical complement pathway inhibits endothelial adhesion molecule expression and preserves ischemic myocardium from reperfusion injury. J. Pharm. Exp. Ther. 286, 1998, p. 429-438.

15. HOMEISTER, J.W. - LUCCHESI, B.R.: Complement activation and inhibition in myocardial ischemia and reperfusion injury. Annu. Rev. Pharmacol. Toxicol. 34, 1994, p. $17-40$.

16. YAO, Z. - RASMUSSEN, J.L. - HIRT, J.L. - MEI, D.A. - PIEPER, G.M. - GROSS, G.J.: Effects of monophosphoryl lipid A on myocardial ischemia/reperfusion injury in dogs. J. Cardiovasc. Pharmacol. 22, 1993, p. 653-663. 
17. ZHAO, L. - KIRSCH, CH.C. - HAGEN, S.R. - ELLIOTT, G.T.: Preservation of global cardiac function in the rabbit following protracted ischemia/reperfusion using monophosphoryl lipid A (MLA). J. Mol. Cell Cardiol. 28, 1996, p. 197-208.

18. KUŽELOVÁ, M. - MLADONICKÁ, M. - ŠPERGLOVÁ, L. - STANKOVIČ, M. JUSKO, M. - DUBNIČKOVÁ M. - BUKOVSKÝ M. - ADAMEOVÁ A. STANKOVIČOVÁ T. - SEGINKO J.: Modified lipid A influences myocardial ischemia reperfusion injury at both in vitro and in vivo conditions (In Slovak). Farm. Obzor 74, 2005, p. 251-256.

19. KUŽELOVÁ, M. - MLADONICKÁ, M. - BUKOVSKÝ, M. - DUBNIČKOVÁ, M. ADAMEOVÁ, A. - ŠVEC, P.: NO-synthase inhibitors provide influence on protective effect of modified endotoxine diphosphoryl lipid $\mathrm{A}$ in a rat heart model of ischemic - reperfusion injury. Pharmazie 61, 2006, p. 568-570.

20. YAMASHITA, N. - HOSHIDA, S. - OTSU, K. - TANIGUCHI, N. - KUZUYA, T. -HORI, M.: Monophosphoryl lipid A provides biphasic cardioprotection against ischemiareperfusion injury in rat hearts. Br. J. Pharmacol. 128, 1999, p. 412-418.

21. TOSAKI, A. - MAULIK, N. - ELLIOTT, G.T. - INGOLF, E.B. - ENGELMAN, R.M. DIPAK, K.D.: Preconditioning of rat heart with monophosphoryl lipid A: a role for nitric oxide. J. Pharmacol. Exp. Ther. 285, 1998, p. 1274-1279.

Registered: April 15, 2011

Accepted: $\quad$ May 5, 2011
Mgr. Martina Dubničková, PhD.

Faculty of Pharmacy

Comenius University

Odbojárov 10

83232 Bratislava

Slovak Republic 


\title{
VPLYV ANALÓGOV LIPIDU A KMEŇOV E. COLI NA KOMPLEMENTOVÚ A MYELOPEROXIDÁZOVU AKTIVÁCIU POČAS REPERFÚZIE PO ISCHÉMII SRDCA POTKANOV
}

\author{
${ }^{I}$ Dubničková M. $-{ }^{2}$ Stankovičová T. $-{ }^{1}$ Bukovský M. $-{ }^{2}$ Kuželová M. \\ Univerzita Komenského v Bratislave, Farmaceutická fakulta, ${ }^{1}$ Katedra bunkovej a molekulárnej \\ biológie liečiv, ${ }^{2}$ Katedra farmakológie a toxikológie \\ Ciel'om práce bolo zistit', či analógy lipidu A získané z natívneho kmeňa (LAS), a z kmeňa \\ E. coli rezistentného na amínoxid (modLANO) alebo na kvartérnu amóniovú sol' (modLBr) \\ znižujú ischemicko - reperfúzne poškodenie srdca potkanov. Lipid $\mathrm{A}$ z rezistentného kmeňa $E$. \\ coli na amínoxid (modLANO 0,5 mg/kg i.v.) neznížil v in vitro pokusoch po 10 minút trvajúcej \\ ischémii srdca a následnej 10 min reperfúzii myeloperoxidázovú (MPO) ani komplementovú \\ aktivitu pri rôznej dížke predliečenia $(0,5,2,4,24 \mathrm{~h})$ potkanov. $\mathrm{V}$ in vivo pokusoch $24 \mathrm{~h}$ \\ predliečenie potkanov s modLANO v dávke $0,5 \mathrm{mg} / \mathrm{kg}$ i.v. významne znížilo MPO aj \\ komplementovú aktivitu $\mathrm{v}$ sére $(\mathrm{p}<0,01)$. Analógy lipidov A prejavili schopnost' ovplyvnit' \\ poškodenie myokardu v podmienkach ischémie a reperfúzie v závislosti od času pôsobenia a ich \\ štruktúry.
}

Acta Facult. Pharm. Univ. Comenianae 58, 2011, p. 7 - 16. 